\title{
THE SUBMISSION OF PUBLIC FACILITIES FOR THE DEVELOPER SUSTAINABILITY*
}

\author{
Bambang Slamet Riyadi** \\ Criminal Law, Faculty of Law, Universitas Nasional, Jakarta \\ Jalan Sawo Manila, Pasar Minggu DKI Jakarta 12520
}

\begin{abstract}
This research analyzes the submission of the public facility and social facility by a developer in the city of Depok. This research also analyzes the implication of the submission inconsistencies in the implementation of public facilities and social facilities. This research is normative legal research method covering investigation of legal principles and law norms related to the submission of public and social housing facilities by the developer. The research results show that the developer has submitted the public housing facilities, but has not properly submitted the social facilities namely sport center and the mosque which have ever been promised or informed to the house owners. The deviation of submission give impact on the following project. The community does not trust the Developer.
\end{abstract}

Keywords: public facility, social facility, developer.

\section{Intisari}

Penelitian ini menganalisis penyediaan fasiltas umum dan fasilitas sosial yang dibangun oleh sebuah perusahaan pengembang di kota Depok. Penelitian ini juga menganalisis dampak perubahan penyediaan fasilitas umum dan fasilitas sosial perumahan terhadap keberlangsungan usaha pengembang. Penelitian ini adalah metode penelitian hukum normatif yang mencakup asas-asas hukum dan kaidah hukum yang relevan dengan penyediaan fasilitas umum dan fasilitas sosial perumahan oleh suatu pengembang. Hasil penelitian menunjukkan bahwa Pengembang telah memenuhi kewajiban menyediakan fasilitas umum, namun tidak melaksanakan penyerahan fasilitas sosial berupa pusat olahraga dan masjid sebagaimana telah pernah dijanjikan dan dipublikasikan kepada para pemilik rumah. Penyimpangan tersebut berakibat terhambatnya kelangsungan usaha pengembang, Masyarakat kurang percaya kepada Pengembang.

Kata Kunci: fasilitas umum, fasilitas sosial, pengembang.

\section{Pokok Muatan}

A. Background 380

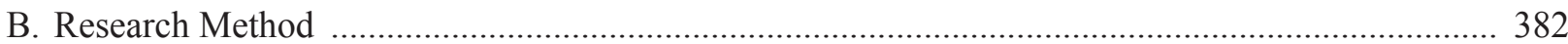

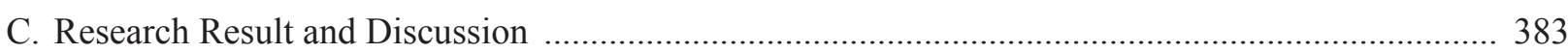

1. The Submission of The Public Facility and Social Facility by The Developer .......................... 383

2. The Implementation of The Submission Inconsistencies in The Implementation of Public

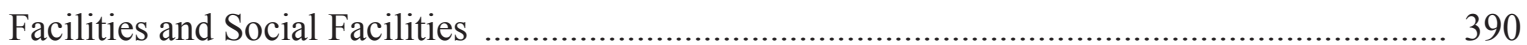

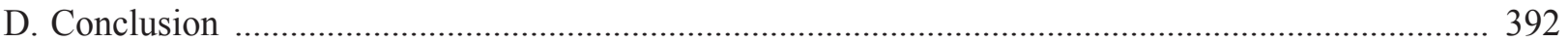

Penelitian dengan Pendanaan Mandiri Penulis.

Correspondence address: bambangsr.kriminologi.ui@gmail.com 


\section{A. Background}

House is one of the basic human needs that will continue to exist and develop in accordance with the stages or cycles of human life. In addition, to protection against natural disturbances as well as weather and other creatures, house also has a social function as a family education center, nursery culture, the value of life, preparing the young generation, and as a manifestation of identity. Within the framework of ecological relationship between human settlements and the environment, it appears that the quality of human resources in the future is strongly influenced by the quality of housing and human settlements where occupied. The fulfillment of housing needs for the community is not easy, especially those who live in densely populated urban areas.

The improved quality of life that is realized through national development should be followed by the improvement in the quality of housing. Improvements are not only in terms of quantitative, but also in qualitative to allow the implementation of housing in accordance with the nature and its function.

The housing and settlement development face the challenges of an increasingly complex, and not entirely accommodated in the development of the region. Strategic issues now faced by the housing and settlement development are the increasing need for housing and residential land in urban areas which tend to be expensive. This is caused partly because an increase in function of the area, the needs of the home per year for new households will enter the housing market, the launching of the Central Government program in building a thousand towers simple flats, slums in urban areas, and the implementation of the concept of environmentally balanced residential that the rules have been issued since in 1992, but has not been established yet.

The development in the field of housing and community-based settlement gives rights and greater opportunities for people to participate. In line this community participation in the development of housing and settlements, the Central Government has the obligation and responsibility to provide guidance in the forms of regulation and guidance, education and training, assistance and services, research and development covering various aspects related to, among others, zoning, land, environmental infrastructure, industrial materials and components, construction and engineering, financial, institutional, human resources, and legislation that support.

The creation of a residential neighborhood and decent housing, clean, healthy, safe and needs to be improved through regulation that ensures the provision and management of water supply, social and religious, economic and transport facilities, recreation and sports facilities, as well as environmental infrastructure, including wastewater facilities, accompanied efforts to increase community awareness and responsibility so that more and more people who live in a healthy home environment.

Functionally, most of the quality of housing and settlements still limited and not sufficient to meet the standard of care appropriate to the scale defined area, both as a residential area as well as a sustainable residential area. There are still many areas that have not been adequately equipped with infrastructure and supporting facilities, such as drainage of rain water green open spaces, sports fields, places of business and commerce, social facilities and public facilities, as well as the persistence of the lack of public utilities, especially water.

Physically, the environment are still prevalent residential areas and settlements have exceeded the carrying capacity and carrying capacity, facing the impact of each relationship with other surrounding areas, as well as its integration issues with infrastructure systems and facilities, both urban and rural areas. The impact of the decrease in the carrying capacity of the environment include an increase in slum areas annually. The change of land use to accommodate the needs of housing and settlement as well as the process of urbanization also have an impact on the environment, including 
in terms of biodiversity, and the emergence of gaps those are not always be anticipated.

Housing development should receive serious attention from the Government, because housing is one of human rights. ${ }^{1}$ It has been mandated expressly in Article 28H Paragraph (1) of 1945 Constitution which states: "Everyone has the right to live physical and spiritual prosperity, residence, and get a good environment and healthy and receive medical care." Consistent with the provisions of the Constitution, Article 40 of Law Number 39 of 1999 concerning Human Rights also states that: "Everyone has the right for a place to live and decent." Furthermore, Article 9, paragraph (1) through paragraph (3) Law Number 39 of 1999 affirmed the right to live as a human right.

In addition, as part of the international community who signed the Declaration of Rio de Janeiro, Indonesia has always been active in the activities initiated by the United Nations Centre for Human Settlements. The spirit embodied in Agenda 21 and the Declaration of Habitat II is that the home is a basic human need and the rights of all people and affordable housing (adequate and affordable shelter for all). In the Agenda 21 emphasized the importance of the home as a human right. It was also in line with the spirit of the Constitution of the Republic of Indonesia Year 1945.

Besides, having the basic constitutional provisions relating to human rights, housing has now also been governed by the Republic of Indonesia Law Number 1 of 2011 (hereinafter referred to as Law Number 1 of 2011 concerning Housing and Settlement Region. This law established the basis that everyone deserves life physical and spiritual prosperity, residence, and get a good environment and healthy living, which is a basic human need, and that has a very strategic role in the formation of character and personality of the nation as one an effort to build a complete Indonesian man, independent, and productive. Thus, the state's responsibility to protect all the people of Indonesia through the implementation of housing and residential areas so that communities are able to live and inhabit the housing and affordable housing in a healthy, safe, harmonious, and sustainable throughout Indonesia. Obligation to provide public facilities and social facilities for Developer has been governed by the provisions of the legislation, but it still happens also Developer who do not carry out its obligations to deliver public facilities and social facilities as planned, or giving public facilities and social facilities but not in accordance with the planning.

The implementation of housing must meet several principles as stated in Law No. 1 of 2011 which are as follows. First, the principle that the welfare of the requirement for adequate housing for the community can be met so that people are able to develop themselves and civilized, and can carry out its function. Second, the principle of independence and togetherness, which is providing housing and residential areas rests on initiative, self-help, and the role of the community to participate and pursue the procurement and maintenance of the aspects of housing and residential areas so as to generate confidence, ability, and the strength of its own, and the creation of cooperation between stakeholders in the field of housing and residential areas. Third, the principle of harmony and balance, namely the implementation of housing and residential areas is done by realizing harmony between structure and pattern of spaces, the harmony between human life with the environment, the balance of growth and development among regions, and considering the significant impact on the environment.

The implementation of housing is done to meet the needs of the home as one of the basic human needs for improvement and equalization of social welfare, which includes estate planning, residential development, utilization and control of residential housing. Although the obligation of the provision of public and social facilities for developers has been governed by the provisions of the legislation, but it still happens also developers who do not fulfill their 
obligation to submit a public facilities and social facilities as planned, or hand over public facilities and social facilities but does not fit with that has been planned.

Based on the previous background, two legal problems to be answered in this research as following: first, the submission of the public facility and social facility in the first housing project by a developer in the city of Depok; and second, the implication of the non submission or deviation of the social facilities in the first housing project on the continuation of the business of the Developer especially in the second housing project.

\section{B. Research Method}

This study is a descriptive study ${ }^{2}$, which is intended to provide the data as thoroughly as possible about the implementation of the obligations of housing Developer to provide and deliver public and social housing facilities under the provisions of the legislation. From the point of form ${ }^{3}$, form prescriptive study, which aimed to get suggestions on what should be done by a real estate development company in order to overcome obstacles to the continuation of the company's business, particularly in the housing market can be overcome.

The research method used in this study is normative that will be conducted by analyzing library materials or secondary data. However, this study is also empirical by analyzing the implementation of the provision of public facilities and the provision of social facilities and the implications of not implementing that has been informed to house buyers.

This research is conducted at the housing complex located in the both first phase and the second phase of house development conducted by the Developer. The second phase housing complex is located near the first phase of housing complex that had already been built and occupied by the buyers or homeowners.
The research uses or focuses more on library materials or secondary data, so it does not require respondents and informants to obtain research data. However, this study also uses data in the form of statements from residential buyers prepared by the Developer. The secondary data used consists of: primary legal materials in the form Basic Law of the Republic of Indonesia Year 1945, the Republic of Indonesia Act Number 1 Year 2011 on Housing and Settlement Region, the Republic of Indonesia Law Number 8 Year 1999 concerning Consumer Protection, Regulation of the Minister of Home Affairs Number 9 of 2009 concerning Guidelines for Delivery of Infrastructure, Facilities and Utilities Housing and Settlement in the Region, Law Number 32 of 2004 concerning Regional Government. Secondary legal material used consists of principles, doctrines, opinions of experts from the law books and other legal writings that can shed light on the primary legal materials.

In this study, the data obtained by studying the document or library materials as a means of data collection written by using content analysis. The documents collected in the form of primary legal materials, secondary legal materials and tertiary legal materials. Primary legal materials are materials derived the Constitution of the Republic of Indonesia Year 1945 and the regulations of the relevant legislation. This study collects various regulations related to housing, particularly regarding the obligation of the developer as a business institution to provide that in accordance with the plan of public facilities and social facilities. Secondary legal material consists of the principles, doctrines, expert opinions contained in the legal literature and legal papers that are written by experts, the results of legal research that can shed light on the primary legal materials. ${ }^{4}$

Data already collected were analyzed using qualitative normative methods, in the form of exposure and thorough depiction of the problems

\footnotetext{
Soerjono Soekanto, 2010, Pengantar Penelitian Hukum, UI-Press, Jakarta, p. 9.

Ibid., p. 10. Soerjono Soekanto mentions that "Prescriptive research aimed to get advice on what to do to solve certain problems."

Soerjono Soekanto dan Sri Mamudji, 2011, Penelitian Hukum Normatif, Raja Grafindo Persada, Jakarta, p. 24
} 
examined, namely about legislation. The first analysis concerns with the national legislation related to housing and residential areas in general. The second analysis concerns the delivery of public facilities and social facilities to the community through local government in particular.

\section{Research Result and Discussion}

1. The Submission of The Public Facility and Social Facility by The Developer

\section{a. The Constitutional and Law Basis of Housing Development}

Housing has had a constitutional basis as set out in Article $28 \mathrm{H}$ paragraph (1) Constitution Year 1945 of the Second Amendment in the Year of 2000 which states that: "Everyone has the right to live in physical and spiritual prosperity, residing and earn a good and healthy living environment." From the provision can be seen that reside on the environment is good and healthy is a human right that has been assigned the constitutional protection. ${ }^{5}$ Outdoor living has a strategic role in the formation of character and personality of the nation in an effort to build a complete Indonesian man, and productive, thus the requirement for housing is a basic need for every human being, which will continue to exist and develop in line with expectations or human life cycle.

In addition to having a constitutional basis, housing has also been set up by Law Number 1 of 2011 concerning Housing and Settlement Region. This Law establishes the basis that everyone deserves life in physical and spiritual prosperity, and get a good environment and healthy living, which is a basic human need, and that has a very strategic role in the formation of character and personality of the nation as one an effort to build a complete Indonesian man, character, independent, and productive. The State has responsibility to protect all the people of Indonesia through the implementation of housing and residential areas so that communities are able to live and inhabit the housing and affordable housing in a healthy, safe, harmonious, and sustainable throughout Indonesia. Consequently, the Government needs to play a greater role in providing assistance and provide facilities and housing and residential areas for the community through the organization of housing and the residential area that is based on selfreliance and community that is an integral function in the form of physical layout, the economic, social and cultural afford ensure environmental sustainability in line with the spirit of democracy, autonomy, and openness in the order of the society, nation and state. ${ }^{6}$

The Regulation of the Minister of Home Affairs No. 9 of 2009 on Guidelines for Submission of Infrastructure, Facilities, and Utilities Regional Housing and Settlements in effect since January 29, 2009. These regulations revoke and declare void Minister Regulation No. 1 of 1987. Minister Regulation No. 1 of 1987 concerning on the Transfer of Environmental Infrastructure, Public Utilities and Social Housing Facilities to Local Government. This regulation is formed by the consideration that in order to support the successful implementation of the development program, it is necessary to set out policy and further guidance on the delivery of environmental infrastructure, public utilities and social facilities housing in residential neighborhoods to the Regional Government. Housing and Corporate Housing Development others in order to carry out the task of providing residential environment healthy and construction of housing and

Jimly Asshiddiqie, 2012, Pengantar Ilmu Hukum Tata Negara,Konpres, Jakarta, pp. 360-361.

Considerations Section of the Law Number 1 of 2011 concerning Housing and Settlement Region (State Gazette of the Republic of Indonesia Year 2011 No.7, Supplement to State Gazette of the Republic of Indonesia No.5188). 
environment infrastructure, public utilities and social facilities needed anything guidelines and the further elaboration of the procedures for the delivery of environmental infrastructure, utilities and social facilities and neighborhoods built by the construction company Housing Company and other housing to local governments. Construction of housing and the environment are now reaching developments in such a way so as to continuity of maintenance and management require handling intensive because on one hand the ability of local authorities, especially regarding the provision of funds and the administration is very limited and on the other hand the growth of urban environment more rapidly, it is necessary to set things leaning the interests of all parties, especially regarding infrastructure standards, the procedures for submission and maintenance budget and management.

Regulation of the Minister is made with the consideration that in order to guarantee the availability of infrastructure, facilities, and utilities housing and settlement, is necessary to manage infrastructure, facilities, and utilities. In order to sustainably manage infrastructure, facilities, and utilities housing and settlement needs to be done delivery infrastructure, facilities, and utilities from developers to local governments. Another consideration is that the Minister Regulation No. 1 Year 1987 on the Transfer of Environmental Infrastructure, Public Utilities and Social Housing Facilities to Local Government is not in accordance with the development of the situation, so it needs to be replaced.

The Management infrastructure, facilities, and utilities that have been submitted to local governments entirely the responsibility of the local authorities concerned. The local government can work together with developers, private enterprises and communities in the management or infrastructure, facilities, and utilities in accordance with the provisions of the legislation. If local governments do the same job management infrastructure, facilities, and utilities with developers, private enterprises, and the public, maintenance of physical and financial infrastructure, facilities, and utilities are the responsibility of the manager. The business infrastructure, facilities, and utilities cannot change the allocation of infrastructure, facilities, and utilities. ${ }^{7}$

Regent/Mayor submit progress reports delivery infrastructure, facilities, and utilities in the region to the governor periodically every 6 (six) months. Governor submits the report submission development infrastructure, facilities, and utilities in its territory to the Minister on a regular basis every year. ${ }^{8}$

b. Principles of Real Estate Law and The Purposes of Housing Administration and Residental Areas

Principles of Real Estate Law was held with some of the principles mentioned in the Article 2 and explanation at Law Number 1 of 2011 as follows.

First, the principle of welfare, which provides a foundation that needs housing and residential area that is viable for the community can be met, so that the communities are able to develop themselves and civilized, and can perform their social function. Second, the principle of justice and equity, which provides the foundation for the results of development in the field of housing and residential areas can be enjoyed proportionately and equitably for all citizens. Third, the 
principle of efficiency and expediency, which provide the foundation so as the housing and residential areas is done by maximizing the potential of the form of land resources, technology design, and healthy building materials industry to provide advantages and benefits for the greater welfare of the people. Fourth, the principle of independence and togetherness, which provides a basis so as the housing and residential areas rests on the initiative, self-reliance, and the role of the public to participate in the procurement and maintenance efforts on aspects of housing and residential areas so as to generate confidence, ability, and strength of their own, as well as the creation of cooperation between stakeholders in the field of housing and residential areas. Fifth, the principle of partnership, which provides a basis so as the housing and residential areas by the Government and the local government by involving businesses and people, with the principle of mutual need, trust, strengthen and benefit made, either directly or indirectly. Sixth, the principle of harmony and balance, which provides a basis so as the housing and residential areas conducted by achieving harmony between the structure of space and spatial patterns, harmony between human beings with the environment, the balance of growth and development among regions, and considering the significant impact on the environment. Seven, the principle of integration, which provides the foundation so that the implementation of housing and residential areas carried out by integrating policies in the planning, implementation, utilization, and control, both intra and inter-agency and related sectors in the whole round and whole, mutually supportive and complementary. Eighth, the principle of health, which provides the foundation for development of housing and residential areas meet the standards of home health, environmental health requirements, and healthy behavior. Ninth, the principle of conservation and sustainability, which provides a foundation, so that the provision of housing and residential areas is done by taking into account environmental conditions, and adjust to the growing need in line with the rate of population increase and the total area of a harmonious and balanced for the current generation and the next generations.Tenth, the principle of safety, security, order, and regularity, which provides the foundation so that the implementation of housing and residential areas concerned with the safety and security of buildings and infrastructure, and the safety and security environment of the various threats that endanger the occupants, administrative order, and regularity in the use of housing and settlement area. ${ }^{9}$

There are several purposes of housing administration and residential areas which are mentioned by the Article 3 of Law Number 1 of 2011 as follows. Housing and residential areas organized to provide legal certainty in the administration of housing and residential areas, the legal guarantee for everyone to live a decent, both owner and non-owner. Legal guarantees include allocation in spatial suitability, legality land, licenses and conditions of eligibility as stipulated in the legislation.

The implementation of housing and residential areas to support the structuring and development of the region as well as a proportional distribution of the population through the growth of residential and settlement areas in accordance with the layout to achieve a balance of interests, especially for low income people, namely the planning,

Article 2 and explanation Act Number 1 of 2011 concerning Housing and Settlement Region (State Gazette of the Republic of Indonesia Year 2011 No.7, Supplement to State Gazette of the Republic of Indonesia No. 5188). 
development, utilization and control is done to maintain harmony, balance and coherence between regions, between the center and the regions, between sectors, and inter interest holders, some major and the development of urban and rural population distribution can redirect and reduce development imbalances between regions and spatial discontinuity.

The implementation of housing and residential areas to empower the stakeholders in the construction of housing and residential areas. Empowering stakeholders is an effort to increase the role of the community by mobilizing potential and resources in proportion to realize the housing and civil settlements. Stakeholders include the public, private sector, financial institutions, governments and local governments.

The implementation of housing and residential areas supports in developing the economic, social, and cultural. Implementation of housing and residential areas and to ensure the realization of decent housing and affordable in an environment that is healthy, safe, harmonious, orderly, well-planned, integrated, and sustainable. Home that is livable and affordable means are homes that meet the safety requirements of the building and a building area of minimum adequacy and health of its inhabitants, which can be reached by the whole society. Healthy environment, safe, harmonious, orderly, well-planned, integrated, and sustainable is an environment that meets the spatial requirements, suitability of land and houses, and the availability of infrastructure, facilities, and public utilities which meet the requirements of environmental quality standards.

Implementation of housing and residential areas requiring guidance by the Central Government, District or Provincial
Government and city government. For that, Act Number 1 Year 2011 specify the duties and authority of the Central Government to conduct training conducted by the central, provincial and district/city governments in accordance with their respective authority. In carrying out the development of housing and residential areas, the central government has the authority as follows.

First, prepare and establish norms, standards, guidelines and criteria for the house, housing, and environment of decent, healthy, and safe. Second, prepare and provide the data base about housing and residential areas. Third, establish and refine the rules of housing and the settlement area. Fourth, the coordination, synchronization, and dissemination of legislation and implementation of policies and strategies for housing and residential areas in order to create security and legal certainty and legal protection in the residence. Fifth, coordinate supervision and control of the implementation of legislation in housing and residential areas. Sixth, to facilitate the management of infrastructure, facilities, housing and public utilities and residential areas. Seventh, to facilitate cooperation between national and international government and legal entities in the administration of housing and residential areas. Eighth, to establish national policies and strategies in the implementation of housing and residential areas. Ninth, to facilitate the management of infrastructure, facilities and public utilities housing and residential areas. Tenth, to establish national policies and strategies in the implementation of housing and residential areas. Ninth, to facilitate the management of infrastructure, facilities and public utilities housing and residential areas. ${ }^{10}$

The Provincial Government in im-

10 Article 13 Act Number 1 of 2011 concerning Housing and Settlement Region (State Gazette of the Republic of Indonesia Year 2011 No.7, Supplement to State Gazette of the Republic of Indonesia No.5188). 
plementing development organization of housing and residential areas have the following tasks.

First, to formulate and establish policies and strategies at the provincial level in the field of housing and residential areas based on the national policy. Second, to formulate and establish provincial policy on utilization and utilization of engineering and technology in the field of housing and residential areas based on the national policy. Third, to formulate and establish policies and Lisiba Kasiba provision across districts / cities. Fourth, to oversee the implementation of national policies and strategies at the provincial level in the field of housing and residential areas. Fifth, perform the functions of operationalization and coordination of the implementation of provincial policies providing home, residential, residential, residential neighborhood, and residential areas. Sixth, to plan development and development of housing and residential areas across districts / cities. Seventh, to facilitate the management of infrastructure, facilities, housing and public utilities and residential areas at the provincial level. Eighth, to allocate funds and / or development costs to support the realization of low-income housing. Ninth, facilitate the provision of housing and residential areas for the community, especially for the low-income communities. Tenth, to facilitate the implementation of policies and strategies at the provincial level. ${ }^{11}$

The provincial government in implementing the guidance the implementation of housing and residential areas have the authority as follows.

First, to compile and provide a database of housing and residential areas at the provincial level. Second, develop and refine the laws and regulations of housing and residential areas at the provincial level. Third, to empower stakeholders in the field of housing and residential areas at the provincial level. Fourth, the coordination, synchronization, and dissemination of legislation and policies and strategies for the implementation of housing and residential areas at the provincial level in order to realize and guarantee legal certainty and legal protection in living. Fifth, to coordinate the use of technology and an environmentally friendly design and use of building materials industry that prioritizes domestic resources and local knowledge. Sixth, coordinating monitoring and controlling the implementation of legislation, policies, strategies, and programs in the field of housing and residential areas at the provincial level. Seventh, evaluate legislation and policies and strategies for the implementation of housing and residential areas at the provincial level. Eighth, facilitating the improvement of the quality of the slums and slum at the provincial level. Ninth, coordinate provisioning or supply of land for housing and settlement development for low-income people at the provincial level. Tenth, to set policy and provincial strategies in the implementation of housing and residential areas based on the national policy. Eleventh, to facilitate cooperation at the provincial level between the provincial government and legal entities in the implementation of housing and residential areas. ${ }^{12}$

The city government in carrying out the implementation of housing development and residential areas have the following tasks: ${ }^{13}$

\footnotetext{
11 Article 14 Act Number 1 of 2011 concerning Housing and Settlement Region (State Gazette of the Republic of Indonesia Year 2011 No.7, Supplement to State Gazette of the Republic of Indonesia No. 5188).

12 Article 17 Act Number 1 of 2011 concerning Housing and Settlement Region (State Gazette of the Republic of Indonesia Year 2011 No.7, Supplement to State Gazette of the Republic of Indonesia No. 5188).

13 Article 15 Act Number 1 of 2011 concerning Housing and Settlement Region.
} 
a. planning development of housing and residential areas in the district/city;

b. performing the functions of operation and coordination of the implementation of the policy of the district/city in the supply of homes, residential, residential environment, and residential areas;

c. supervising and controling the implementation of legislation, policies, strategies and programs in the areas of housing and residential areas in the district/ city;

d. implementing quality improvement of housing and settlements;

e. implementing policies and strategies of the province in the implementation of housing and residential areas based on the national policy;

f. managing the infrastructure, facilities, housing and public utilities and residential areas.

In order to meet the needs of the home as one of the basic human needs for improved welfare and equity, government, local government and/or any person to guarantee the right of every citizen to occupy, enjoy, and/or have a decent home in a safe environment, safe, harmonious and orderly. ${ }^{14}$ The implementation plan covers residential housing, housing development, utilization and control of residential housing. Housing includes a housing and its infrastructure, facilities, and public utilities. ${ }^{15}$
Estate planning is part of the settlement plan consisting of the planning and designing of homes and infrastructure planning, facilities, housing and public utilities. ${ }^{16}$ Estate planning involves planning of infrastructure, facilities, and public utilities must meet the aspects of administrative, technical, and ecological. Once it has been able to meet the requirements then approval from the local government. ${ }^{17}$ Planning of infrastructure, facilities, and public utilities can be done by any person. Each person must have expertise in the planning of infrastructure, facilities, and public utilities in accordance with the provisions of the legislation. ${ }^{18}$

The submission of infrastructure, facilities, and utilities is the submission of the form of land with buildings and/or land without a building in the form of assets and management responsibilities of Developer to local governments. ${ }^{19}$ Regulation of the Minister of Home Affairs Number 9 Year 2009 uses the term infrastructure, facilities and utilities. Infrastructure is the physical basis of the completeness of an enabling environment for housing and residential environment to function properly. ${ }^{20}$ Facilities is a facility that serves to support the implementation and development of the economic, social, and cultural. ${ }^{21}$ Utilities are supporting facilities for environmental services. $^{22}$

The submission of infrastructure, facilities, and utilities in the area of housing and settlements

14 Article 19 Act Number 1 of 2011 concerning Housing and Settlement Region (State Gazette of the Republic of Indonesia Year 2011 No.7, Supplement to State Gazette of the Republic of Indonesia No.5188).

15 Article 20 Act Number 1 of 2011 concerning Housing and Settlement Region (State Gazette of the Republic of Indonesia Year 2011 No.7, Supplement to State Gazette of the Republic of Indonesia No.5188).

16 Article 23 Act Number 1 of 2011 concerning Housing and Settlement Region (State Gazette of the Republic of Indonesia Year 2011 No.7, Supplement to State Gazette of the Republic of Indonesia No.5188).

17 Article 29 Act Number 1 of 2011 concerning Housing and Settlement Region (State Gazette of the Republic of Indonesia Year 2011 No.7, Supplement to State Gazette of the Republic of Indonesia No.5188).

18 Article 30 paragraph (1) Act Number 1 of 2011 concerning Housing and Settlement Region. (State Gazette of the Republic of Indonesia Year 2011 No.7, Supplement to State Gazette of the Republic of Indonesia No.5188).

Article 1, point 4 Regulation of the Minister of Home Affairs No. 9 of 2009.

Article 1, point 1 Regulation of the Minister of Home Affairs No. 9 of 2009

Article 1, point 2 Regulation of the Minister of Home Affairs No. 9 of 2009

Article 1 point 3 Regulation of the Minister of Home Affairs No. 9 of 2009. 
made with the principles as set out in Article 3 of Regulation of the Minister of Home Affairs Number 9 of 2009 as follows.

First, the delivery of infrastructure, facilities, and utilities in the area of housing and settlements executed by the principles of openness, people would know the infrastructure, facilities, and utilities that have been submitted and or easier for citizens to access information related to the delivery of infrastructure, facilities, and utilities. Second, the principle of accountability, which is the process of handover infrastructure, facilities, and utilities that can be accounted for in accordance with the statutory provisions. Third, the principle of legal certainty, which ensures the certainty of the availability of infrastructure, facilities, and utilities in the housing and settlement in accordance with the standards, site plans approved by the local government, as well as the conditions and needs of the community. Fourth, the principle of partisanship, the government guarantees the availability of infrastructure, facilities, and utilities for the benefit of society in the housing and settlement. Fifth, the principle of sustainability, which ensures the existence of local government infrastructure, facilities, and utilities in accordance with the functions and purposes.

The submission of infrastructure, facilities, and housing and settlement utilities from Developer to local governments as contained in Article 2 of the Ministry of Home Affairs Number 9 of 2009 aims to ensure the sustainability of the maintenance and management of infrastructure, facilities, and utilities in residential neighborhoods and settlements. Housing and settlement infrastructure which include roads, drainage sewerage network or drainage of rain water, and landfills. ${ }^{23}$ Housing and settlement consists of a means of commerce / shopping, public services and government facilities, educational facilities, health facilities, facilities for religious, recreational and sports facilities, means of burial, the means landscaping and green space and parking facilities. ${ }^{24}$ Housing and settlement utilities consist of water supply networks, power grids, telephone networks, gas networks, transportation networks, fire and general service lighting facilities. ${ }^{25}$

Housing Developer or real estate developer or usually abbreviated developer or Developer are individuals or companies who work on developing a residential area into habitable housing and economic value that can be sold to the public. Developer can also work to build or modify a residential or an existing building, so a housing/building will be a newer, better, and have a higher economic value. ${ }^{26}$

Developer also can be categorized as entrepreneurs. Article 1 paragraph 3 of Law Number 8 of 1999 concerning Consumer Protection defines entrepreneurs is any individual or entity, whether incorporated or not a legal entity established and domiciled or conducting activities within the jurisdiction of the Republic of Indonesia, either alone and together through agreements carry on business in various economic fields. ${ }^{27}$

Business actors have an obligation are as follows. First, acting in good faith in the conduct of its business. Second, provide correct, clear and honest about the condition and guarantee the goods and/or services as well as to explain the use, repair and maintenance. Consumer Protection Act determines the restrictions imposed on businesses. Offender shall be prohibited from trading goods

\footnotetext{
Article 8 Regulation of the Minister of Home Affairs No. 9 of 2009.

Article 9 Regulation of the Minister of Home Affairs No. 9 of 2009.

Article Regulation of the Minister of Home Affairs No. 9 of 2009.

R. Serfianto Dibyo Purnomo, et al., Op.cit., p. 11.

Law Number 8 of 1999 concerning Consumer Protection was formed with consideration between that national development is aimed at establishing a just and prosperous society equitable materially and spiritually in an era of economic democracy based on Pancasila and the Basic Law of 1945. National economic development in globalization era must be able to support the growth of the business so as to produce various goods and / or services that contain technology that can improve the welfare of the community at large and also get the assurance of goods and / or services obtained from the trade without causing harm consumers. The opening of the national market as a result of the process of economic globalization should still ensure the welfare and kepatian increase the quality, quantity and safety of goods and / or services acquired in the market. To enhance the dignity of consumers need to increase awareness, knowledge, awareness, capability and independence of consumers to protect themselves and to develop an attitude responsible business behavior.
} 
in a state does not meet or do not conform to the required standards and the provisions of laws and regulations, does not match the promise stated in the description, advertisement or sales promotion goods. Additionally, businesses are prohibited from offering, advertise an item incorrectly and/or as if in a state that has a promise to offer something that is not certain. ${ }^{28}$

Offender shall be prohibited from offering, promoting or advertising a product at a price within a certain amount of time and, if these businesses do not intend to do so in accordance with the timing and amount of the offer, promotion, or advertising. ${ }^{29}$ Business actors in offering goods with orders are not forbidden to keep order and/or a settlement agreement in accordance with the promised and did not fulfill the promise of a service and/or achievement. ${ }^{30}$

\section{The Implementation of The Submission} Inconsistencies in The Implementation of Public Facilities and Social Facilities

a. Consistencies in The Implementation of Public Facilities and Social Facilities

The Developer should be consistent with what he had promised. Consistency is as defined by Article 134 of the Law Number 1 of 2011 which states that every person is prohibited conduct residential development, which does not build housing in accordance with the criteria, specifications, requirements, infrastructures, facilities, and public utilities were agreed.

At the location used as a study, the entrance to the residential locations have formed during the development of the first phase and the road is used to access the site will be developed in phases with wide twolane road with a pavement of 4,5 meters. In general, maintenance of roads in the area are well maintained with cast concrete and asphalt condition.

Facilities of electricity, water and telephone are available in this area, while public city transport pass highway road in front of residential location. Major road network and the environment in the housing are well maintained and for the development of the second phase is planned infrastructure required conditions corresponding intermediate type of house built with wide main street in residential ROW ten with two lanes with pavement six meter and the environment in accordance with the type of road that was built there ROW eight and seven feet.

Disposal of waste water and storm water disposal distributed through channels on either side of the road, and for the channel crossing the road would be made of reinforced concrete culverts. Social facilities available can be used as an open area for landscaping or open space in addition to functioning as the lungs, it can also serve as a children's play area or other open space can be used for a sports or social activities as a means of places of worship and others.

The Developer have been trying to fulfill its obligations under the provisions of the legislation in the field of housing and residential areas. Here is a description that proves the implementation of the obligations of the Developer. First, at this stage of estate planning, Developer Company has complied with the planning of housing to meet the housing needs not only includes planning and design of the house, but Developer have provides facilities, housing and public utilities. ${ }^{31}$ Second, at the planning and design of homes, The Developer have made the planning and designing houses that meet 
the administrative, spatial and ecological technical requirements. ${ }^{32}$ The proof is that the Developer managed to get a building permit, where the permit can only be obtained if the Developer has met the three with the above requirements. ${ }^{33}$

Third, at the planning stage of infrastructure, facilities and public utilities, Developer should plan the provision of land and housing completeness of public utilities. Planning has met the administrative, technical and ecological requirements. The proof is that this plan has received the approval from the City Government. ${ }^{34}$

Fourth, at this stage of residential development, Developer have done residential construction of public facilities. Developer have done a duty handed public facilities such as road infrastructure and the environment as well as electricity lines have been installed. The width of the main street in the residential ROW eight meters by five meters pavement. The road environment in accordance with the type of houses built, which consists of the ROW category eight meters and seven meters.

But, in the implementation of the submission of public facilities and social facilities, the Developer have done aberrations, namely that the Developer handed social facilities that do not fit that has been planned. Social facilities such as sports facilities or sports center should be located on land of first Block of Housing covering 280 square meters.

\section{b. Inconsistencies in The Implemen- tation of Public Facilities and Social Facilities}

However, in the implementation of the social facilities, the Developer divert them to another location, namely the area of land located adjacent to the area designated for building mosques located in Block $\mathrm{C}$ of the Housing. But till the time of this Writing, sports facilitie has been yet built. Other irregularities in the implementation of the provision of social facility housing is that it is also up to the time of writing, the mosque also has not been built.

However, after consultation with the Mayor, Developer finally asked the owner of the house in a housing complex of the first phase is to provide a statement regarding the change of location of social facilities were handed over by the Developer. With the letter states the homeowner can actually receive social facilities such as most land area of $280 \mathrm{~m}^{2}$ Block I (two hundred and eighty square meters), was transferred to the mosque so that the total land area of $360 \mathrm{~m}^{2}$ a (three hundred and sixty square feet), in Block C, in accordance with the site plan Housing. The content of the statement is complete homeowners stated that they each might receive the promise with actual donations / aid of the mosque building area of $100 \mathrm{~m}^{2}$ (one hundred square meters) from the Developer in this case by the responsible parties Developer. The concept of plans and specifications of buildings or mosques can be submitted to Developer. Later, after the mosque construction is complete, it can be handed over to the residents of the first phase of the Housing through the City Government or related agencies. ${ }^{35}$

Based on the description and the contents of the letters declaration housing residents, the authors considered that the Developer has acted or acts contrary to the

\footnotetext{
Implementation Developer obligations under Article 26 paragraph (1) Act Number 1 of 2011 concerning Housing and Settlement Region. Permit No. mayor. 468.12/2084-Per/DB/2003 on Building Permit Dated 23 September 2003.

Implementation Developer Obligations under Article 28 paragraph (1) and paragraph (2) jo. Article 29 Act Number 1 of 2011 concerning Housing and Settlement Region.

Statement of homeowners in Housing Complex Phase I which was signed by each homeowner. Statement was prepared by the Developer.
} 
laws and regulations as follows. First, the developer does not perform the submission area dedicated to the sport and also means not building social facilities. Second, the developer does not perform the submission of social facilities such as building mosques worship as previously planned. The act violates the provisions of Article 47 paragraph (2) Law number Year 2011, which states: "The development of infrastructure, facilities, and public utilities shall be done according to plan, design and licensing."

c. The Impact of The Deviation in Providing and Submitting Social Facilities on The Sustainability of The Development of The Housing

The second phase of the housing complex is near from the first phase which was completed earlier. Implementation of second phase of Housing construction began in November 2010 beginning with the pre-construction work. In December 2010 are now conducted a field survey by a consulting firm in research activities Environment Environmental Management and Environmental Monitoring, on-site phase I've built about ten units. Progress in the field has only reached $40 \%$ of approximately ten units. ${ }^{36}$ Progress in the field has only reached $40 \%$.

Based on the site plan or planning the location of housing can be seen that the total land area is $12283 \mathrm{~m} 2$, land use Tugu Housing Residence consists of: kavling effective area of $7,390 \mathrm{~m} 2$ or $60.2 \%$. The rest is earmarked for infrastructure and facilities covering an area of 4,893 $\mathrm{m} 2$ consisting of social facilities and public facilities covering an area of $1,008 \mathrm{~m} 2$, or $8.2 \%$, a garden area of $1,332 \mathrm{~m} 2$, or $10 \%$, road and parking area of $2,553 \mathrm{~m} 2$, or $20.8 \%$.
At the end of 2010 the house was sold to the public. But till the time this thesis was written, marketing activities have been conducted have not produced tangible results. There is no realization of purchase although only one although unitpun offer period has lasted almost two years. This fact can be judged that the irregularities in the implementation of the responsibility to provide and deliver social facilities that the community as a prospective home buyer was not so sure of the credibility or reliability of the second phase housing developer who is also the Housing Developer first phase.

This fact can be understood that the community is very concerned about the rights that are not merely the right to a public facilities, but rather the right to social facilities, in addition to the course, conditions and specifications as published. For Developer circumstances certainly carry a heavy burden of having to bear the burden of bank interest or loans from other parties. Cash flow or cash flow of the company to be disturbed, so as to impede the progress of housing development for the project or other.

\section{Conclusion}

Based on the analyzing, it can be concluded, first, the Developer Company in building housing projects Phase I seeks to fulfill its obligation to submit public facilities and social facilities. Waiver of the buyer or homeowner to prove that the developer has to provide and deliver public facilities such as roads and tract housing in accordance with the master plan and the path to the development of housing facilities. Additionally Developer submit public facilities such as power lines and underground telephone network and network taps. The facility is consistent with the concept of Real Estate Developer.

EA Appraisal Commission Depok, 2011, Research Report and Evaluation Management Efforts and Environmental Monitoring Housing Phase I, Research Report, unpublished, p. II-5. 
Second, however, Estate Developer deviated in providing and submitting social facilities. Originally based planning and publicity to the homeowner, social facilities such as sports facilities or sports center will be built on a land area $280 \mathrm{~m} 2$ (two hundred and eighty square meters) in Block I. But by the Developer, the establishment of land where sports facilities were moved to land near the land planned to build another social facilities are buildings of worship mosques. Total land for social facilities is $360 \mathrm{~m} 2$ (three hundred and sixty square meters) located in Block C.

In addition, the Developer also has promised to deliver social facilities such as mosque building area of $100 \mathrm{~m} 2$ (one hundred square meters) as promised by the Responsible Estate Developer. Building the mosque if it will have been completed, will be submitted by the Developer to the citizens.

However, until this writing, social facilities promised in the form of sports and religious buildings not yet built the Mosque Developer Housing of the first phase. Deviation Developer negatively impact when doing development of the second phase of housing complex, where the marketing of housing units have obstacles that no one is interested buying homes, even after the expiration of less than two years of marketing which coincided with the start of the pre-construction.

\section{REFERENCES}

\section{A. Books}

Purnomo, R. Serfianto Dibyo, et al., 2011, Panduan Lengkap Mengurus Dokumen Properti, Pustaka Yustisia, Yogyakarta.

Soekanto, Soerjono, 2010, Pengantar Penelitian Hukum, UI-Press, Jakarta.

Soekanto, Soerjono dan Mamudji, Sri, 2011, Penelitian Hukum Normatif, Raja Grafindo Persada, Jakarta.

Asshiddiqie, Jimly, 2012, Pengantar Ilmu Hukum Tata Negara,Konpres, Jakarta.

\section{B. Government Regulation}

Act Number 1 of 2011 concerning Housing and Settlement Region (State Gazzete of Indonesian Republic of 2011 No.7, Supplement to State Gazzete No.5188).

Regulation of the Minister of Home Affairs No. 9 of 2009.

Permit No. mayor. 468.12/2084-Per/DB/2003 on Building Permit Dated 23 September 2003.

\section{Research Report}

EA Appraisal Commission Depok, 2011, Research Report and Evaluation Management Efforts and Environmental Monitoring Housing Phase I, Research Report, unpublished. 